\title{
MEDITERRANEAN DIET ADHERENCE AMONG COSMETOLOGY STUDENTS
}

\author{
Małgorzata Jeziorek ${ }^{l}$, Alicja Szypowska ${ }^{I}$, Bożena Regulska-Ilow
}

\author{
${ }^{1}$ Department of Dietetics, Faculty of Health Sciences, Wrocław Medical University, Wrocław, Poland
}

\begin{abstract}
Background. The Mediterranean diet (MD) is universally recognized as the healthiest model of nutrition whose beneficial effects help prevent many diet-related diseases.

Objective. The aim of the study was to assess cosmetology students' adherence to the Mediterranean Diet using the Mediterranean Diet Score (MDS).

Material and methods. The study group consisted of 175 cosmetology students of the School of Physiotherapy whose dietary habits were assessed using a validated food frequency questionnaire (FFQ) consisting of 154 food and drink items representative of the diet during the last year. We analyzed data obtained from FFQ and calculated the average number of daily and/or weekly servings from each of the 9 MDS food groups (grains, vegetables, fruits/nuts, milk/ dairy products, meat/meat products, legumes, alcohol, olive oil, fish). To obtain more reliable results, we analyzed other products consumed by study participants (sweets, beverages, eggs and potatoes). Study participants were assigned 0,1 or 2 points for each MDS ingredient. Mediterranean diet adherence was assessed on a 17-point scale. Low adherence to MD was defined at 0-7 points, moderate at 8-10 points, and high at 11-17 points.

Results. The mean MDS was $7.1 \pm 2.3$. Students who were assigned $11-17$ points $(\mathrm{n}=20)$ consumed significantly more vegetables, fruits, nuts, legumes, fish, olive oil and significantly less meat, meat products, milk, dairy, and sweets compared to study participants who were assigned the lowest number of points $(\mathrm{n}=78)$. We reported significant differences in the amounts of consumed vegetables and sweets between participants who received 8-10 points $(\mathrm{n}=77)$ and those who received 11-17 points. The higher MDS was significantly associated with the higher intakes of vegetables and dietary fiber. Conclusions. The dietary patterns of study group of Polish cosmetology students did not adhere to the MD recommendations.
\end{abstract}

Key words: dietary patterns, dietary recommendations, Mediterranean diet, university students

\section{STRESZCZENIE}

Wprowadzenie. Dieta śródziemnomorska (DŚ) to najzdrowszy model żywienia na świecie, który charakteryzuje się korzystnym działaniem w prewencji wielu chorób dietozależnych.

Cel. Ocena zgodności diet studentek kosmetologii z zaleceniami diety śródziemnomorskiej ocenianej wskaźnikiem Mediterranean Diet Score (MDS).

Material i metody. Grupę badaną stanowiło 175 studentek kosmetologii z Wyższej Szkoły Fizjoterapii. Ocenę sposobu żywienia przeprowadzono za pomocą walidowanego kwestionariusza częstotliwości spożycia żywności FFQ (ang. food frequency questionnaire), który uwzględniał spożycie 154 produktów w ciągu roku poprzedzającego badanie. Na podstawie FFQ obliczono średnią dzienną i/lub tygodniową zawartość w diecie 9 grup produktów spożywczych: składowych wskaźnika MDS (produkty zbożowe, warzywa, owoce i orzechy, mleko i produkty mleczne, mięso i przetwory mięsne, nasiona roślin strączkowych, alkohol, oliwa, ryby) oraz dodatkowych produktów (słodycze, napoje, jaja i ziemniaki), które nie wchodziły w skład wskaźnika, jednak zostały uwzględnione, ponieważ występowały w dietach badanych i mogły istotnie wpłynąć na wynik badania. Zastosowano trzystopniowy system punktacji, w którym uczestnicy otrzymali 0,1 lub 2 punkty za każdy składnik. Wynik możliwy do uzyskania na podstawie wskaźnika MDS wynosił 0-17 pkt., przy czym wyższa liczba uzyskanych punktów oznaczała większą zgodność diety z DŚ. Diety studentek, które otrzymały 0-7 punktów określono jako diety o niskiej zgodności z DŚ, 8-10 punktów - o średniej zgodności Z DŚ, a 11-17 punktów o wysokiej zgodności z DŚ.

Wyniki. Średnia wartość MDS obliczona dla diet studentek kosmetologii wynosiła 7,1 $\pm 2,3$. Diety 20 studentek, które uzyskały wartość wskaźnika MDS w zakresie 11-17 pkt. zawierały istotnie statystycznie więcej warzyw, owoców i orzechów, nasion roślin strączkowych, ryb, oliwy oraz istotnie statystycznie mniej mięsa i jego przetworów, mleka i jego przetworów oraz słodyczy w porównaniu do diet, które uzyskały najmniejszą liczbę punktów (n=78). Dodatkowo występowały istotne różnice między zawartością w diecie warzyw i słodyczy między badanymi, których diety otrzymały

Corresponding author: Alicja Szypowska, Department of Dietetics, Faculty of Health Sciences, Wroclaw Medical University, Poland, Parkowa 34, 51-616 Wrocław, Poland, tel. +48 515-746-698, e-mail: alicja.szypowska@umed.wroc.pl

(C) Copyright by the National Institute of Public Health NIH - National Research Institute 
8-10 pkt. (n=77) w porównaniu do diet, które otrzymały 11-17 pkt. Wraz ze zwiększeniem liczby uzyskanych punktów MDS stwierdzono istotnie większą zawartość warzyw oraz błonnika pokarmowego w dietach badanych studentek.

Wnioski. Diety badanej grupy studentek kosmetologii nie były zgodne z zaleceniami diety śródziemnomorskiej ocenianej wskaźnikiem MDS.

Słowa kluczowe: zwyczaje żywieniowe, rekomendacje żywieniowe, dieta śródziemnomorska, studenci

\section{INTRODUCTION}

The Mediterranean diet (MD) is universally recognized as the healthiest model of nutrition whose beneficial effects help prevent many diet-related diseases, including cardiovascular disease, type-2 diabetes, cancer, and neurodegenerative disorders. The Mediterranean diet is characterized by a high intake of fruits, vegetables, grains, legumes, olive oil, nuts; moderate consumption of eggs, poultry and dairy, low intake of red meat and red wine consumed with meals $[1,13,27]$. This diet has low glycemic index and a relatively high total fat intake, but is low in saturated fatty acids. The main source of fat intake is olive oil. The diet is rich in dietary fiber, antioxidant compounds and bioactive elements with anti-inflammatory effects. Following MD recommendations may help reduce the risk for chronic diseases [18]. Moreover, MD enhances cognition and academic achievements. It has been shown that greater MD adherence was associated with better learning outcomes [1,27].

Early adulthood is often associated with lifestyle changes, including eating habits. If students live away from homes their eating patterns often deteriorate [6]. Students' dietary patterns are generally unhealthy and involve skipping meals and consuming a lot of added sugar, saturated fatty acids and alcoholic beverages, which is very often accompanied by a lack of physical activity. Unhealthy eating habits acquired at young age often translate into health problems associated with poor-quality diet in adulthood [27].

We aimed to assess if dietary habits of Polish cosmetology students complied with MD recommendations.

\section{MATERIAL AND METHODS}

\section{Study group and methods}

The study was conducted in Wroclaw (Poland). The investigation was performer in accordance with the Declaration of Helsinki for Human Research. The research has been approved by bioethical commission of Wroclaw Medical University (No. KB - 519/2019).

The study group consisted of 175 female cosmetology students of the School of Physiotherapy (mean age: $21.3 \pm 3.7$ years; mean BMI: $21.3 \pm 4.2 \mathrm{~kg}$ / $\left.\mathrm{m}^{2}\right)$.

We assessed their dietary habits using a validated food frequency questionnaire (FFQ) consisting of 154 food and drink items representative of the diet during the last 12 months. An average portion size of each product was described, eg. one slice of bread, one glass of milk, one apple, etc. The respondents declared frequency of consumption of each product portion size.

We assessed the frequency of consumption of selected food products on a 9-point scale: never, less than once a month, 1-3 times a month, once a week, 2-4 times a week, 5-6 times a week, once a day, 2-3 times a day, 4-5 times a day, $>6$ times a day [9]. The collected data was entered into Microsoft Excel v. 2010 spreadsheet.

The declared consumption of food products was converted into grams per day, taking into account the average size of consumed portions. Then, the nutritional value of individual students' dietary patterns was calculated according to the Food and Nutrition Institute in Warsaw [16]. Based on the FFQ, we calculated the daily and/or weekly average intake 9 food products: from the MDS (grains, vegetables, fruits and nuts, milk and dairy products, meat and meat products, legumes, alcohol, olive oil, fish) and, to obtain more reliable results, additional products (sweets, drinks, eggs and potatoes).

We used an updated version of the MDS as outlined by Stefler et al. [23] and according to the recommendations on MD indicated by Sofi et al. [22]. We defined absolute cut-off values for all MDS components and applied a three-tier scoring system with 0,1 , or 2 points assigned to participants for each component. For food groups typical of the MD (vegetables, fruits and nuts, legumes, grains and fish) we assigned 2 points for the highest intake, 1 point for moderate and 0 points for the lowest intake [23]. For food groups not typical of the MD (meat, milk and dairy products) we assigned 2 points for the lowest intake, 1 point for moderate and 0 points for the highest intake [22]. The first exception was alcohol whose content was assessed on a three-point scale ( $0-2$ points), but we assigned the highest points for the moderate intake. The second exception was olive oil whose content was assessed on a two-point scale (0-1 points). We assigned 1 point for the declared regular use of olive oil, and 0 points if study participants declared otherwise. We used a 17-point MDS with low MD adherence defined at 0-7 points, moderate at 8-10 points, and high at 11-17 points [23]. The scoring system for each food groups is presented in Table 1. 
Table 1. Three-tier scoring system with 0,1 or 2 points assigned to participants for each food groups [22, 23]

\begin{tabular}{|l|c|c|c|}
\hline \multirow{2}{*}{ Studied parameters } & \multicolumn{3}{c|}{ Three-tier scoring system } \\
\cline { 2 - 4 } & 0 points & 1 point & 2 points \\
\hline Vegetables [g/day] & $<100$ & $100-250$ & $>250$ \\
\hline Fruits and nuts [g/day] & $<150$ & $150-300$ & $>300$ \\
\hline Legumes [g/week] & $<70$ & $70-140$ & $>140$ \\
\hline Grain products [g/day] & $<130$ & $130-195$ & $>195$ \\
\hline Fish [g/week] & $<100$ & $100-250$ & $>250$ \\
\hline $\begin{array}{l}\text { Meat and meat products } \\
\text { [g/day] }\end{array}$ & $>120$ & $80-120$ & $<80$ \\
\hline $\begin{array}{l}\text { Milk and dairy products } \\
\text { [g/day] }\end{array}$ & $>270$ & $180-270$ & $<180$ \\
\hline Alcohol [g/day] & $>24$ & 12 & $12-24$ \\
\hline & $\begin{array}{c}124 \\
\text { olive oil }\end{array}$ & $\begin{array}{c}\text { regular } \\
\text { olive oil }\end{array}$ & \\
\hline Olive oil & & \multicolumn{1}{|c|}{} \\
\hline
\end{tabular}

We assessed if the average intakes of selected food products adhered to MD recommendations. In addition, we compared the average daily intake of energy and dietary fiber between the study groups and compared our results with dietary habits of Greek students in regard cardiovascular risk status [6].

Statistical analysis was performed with STATISTICA v 12.0 PL (StatSoft Inc., USA). The normality of data distribution was tested with the Lilliefors and Shapiro-Wilk tests, and the homogeneity of variance with the Levene test. To compare the three unmatched groups, we used the non-parametric multiple comparison Kruskal-Wallis test. The results were considered statistically significant when $\mathrm{p}<0.05$.

\section{RESULTS}

The mean MDS value for the study participants was 7.1 \pm 2.3 . After analyzing the collected data, we found low MD adherence in $45 \%$ of the study participants (0-7 points), moderate in $44 \%$ (8-10 points), and high in $11 \%$. The dietary patterns of female cosmetology students $(n=20)$ with the highest MDS had statistically significantly higher intake of: vegetables, fruit and nuts, legumes, fish, olive oil and significantly lower intake of meat and its processed products, milk and milk products and sweets compared to diets with the lowest MDS $(\mathrm{n}=78)$. We did not reported differences between grains and alcohol intake.

The dietary patterns of female cosmetology students from the group of moderate MD adherence $(n=77)$ were characterized by a significantly higher intake of vegetables, legumes and olive oil compared to students whose diets had low MDS $(\mathrm{n}=78)$. We did not reported differences between others food group intake. In the group of female students with

Table 2. Comparison of the mean intake of selected food products, the mean daily energy value and nutrients in the diets of female students who were assigned 0-7, 8-10 and 11-17 MDS

\begin{tabular}{|c|c|c|c|c|c|c|}
\hline \multirow{3}{*}{ Studied parameters } & \multicolumn{3}{|c|}{ MDS } & \multicolumn{3}{|c|}{ Kruskal-Wallis test (p) } \\
\hline & 0-7 points & 8-10 points & 11-17 points & \multirow{2}{*}{ A vs. B } & \multirow{2}{*}{ B vs. C } & \multirow{2}{*}{ A vs. C } \\
\hline & $A(n=78)$ & $B(n=77)$ & $\mathrm{C}(\mathrm{n}=20)$ & & & \\
\hline \multicolumn{7}{|c|}{ Food products/groups of food products } \\
\hline Vegetables [g/day] & $277.42 \pm 150.88$ & $355.13 \pm 149.41$ & $516.61 \pm 215.20$ & 0.0003 & 0.0348 & $<0.0001$ \\
\hline Fruits \& nuts [g/day] & $180.23 \pm 114.40$ & $275.98 \pm 112.28$ & $361.34 \pm 115.82$ & NS & NS & $<0.0001$ \\
\hline Legumes [g/week] & $42.77 \pm 70.42$ & $137.62 \pm 127.15$ & $271.00 \pm 281.73$ & $<0.0001$ & NS & $<0.0001$ \\
\hline Grain products [g/day] & $93.53 \pm 46.35$ & $110.30 \pm 60.56$ & $131.07 \pm 77.56$ & NS & NS & NS \\
\hline Fish $[\mathrm{g} /$ week $]$ & $48.06 \pm 34.75$ & $76.73 \pm 71.42$ & $108.5 \pm 86.95$ & NS & NS & 0.0050 \\
\hline Meat \& meat products [g/day] & $141.02 \pm 100.51$ & $113.03 \pm 95.42$ & $72.26 \pm 85.66$ & NS & NS & 0.0007 \\
\hline Milk \& dairy products [g/day] & $284.05 \pm 148.79$ & $251.35 \pm 148.29$ & $198.29 \pm 166.75$ & NS & NS & 0.0436 \\
\hline Alcohol [g/day] & $4.02 \pm 5.05$ & $3.78 \pm 4.58$ & $4.01 \pm 6.15$ & NS & NS & NS \\
\hline Olive oil [g/day] & $6.84 \pm 5.16$ & $12.15 \pm 9.61$ & $12.08 \pm 5.04$ & 0.0003 & NS & 0.0032 \\
\hline Sweets [g/day] & $52.17 \pm 34.27$ & $52.80 \pm 35.53$ & $35.65 \pm 32.51$ & NS & 0.0261 & 0.0305 \\
\hline Beverages [g/day] & $252.63 \pm 230.15$ & $307.53 \pm 320.33$ & $269.38 \pm 355.69$ & NS & NS & NS \\
\hline Eggs [g/day] & $23.16 \pm 29.11$ & $22.92 \pm 23.43$ & $20.43 \pm 16.84$ & NS & NS & NS \\
\hline Potatoes [g/day] & $66.01 \pm 40.97$ & $67.56 \pm 47.97$ & $55.17 \pm 40.52$ & NS & NS & NS \\
\hline \multicolumn{7}{|c|}{ Food energy and nutrients } \\
\hline Food energy [kcal] & $1672.55 \pm 611.06$ & $1815.78 \pm 676.98$ & $1864.36 \pm 831.29$ & NS & NS & $\mathrm{NS}$ \\
\hline Dietary fiber $[\mathrm{g}]$ & $16.20 \pm 6.27$ & $22.83 \pm 7.43$ & $30.02 \pm 9.49$ & $<0.0001$ & 0.0318 & $<0.0001$ \\
\hline
\end{tabular}

A - group with low MD adherence defined at 0-7 points; B - group with moderate MD adherence at 8-10 points; C - group with high MD adherence at 11-17 points;

$\mathrm{p}<0.05-$ statistically significant values. 
moderate MD adherence $(\mathrm{n}=77)$ we reported a statistically significantly lower intake of vegetables and significantly higher intake of sweets compared to dietary patterns of study participants with the highest MD adherence $(n=20)$. We did not reported differences between others food group intake. The average intake of cereals, alcohol, beverages, eggs and potatoes, as well as the energy value did not differ significantly between the studied groups. The above data are presented in Table 2.

\section{DISCUSSION}

We reported that the majority of the studied dietary patterns had low or moderate MD adherence. Only $20.0 \%$ were assigned the highest number of points. In a study assessing eating habits of the students from the Medical University of Lodz, only $1.2 \%$ of women and $0.7 \%$ of men reported MD adherence. More than $80.0 \%$ of the study participants did not follow any special diet [17]. Similar results were obtained by Zych et al. [28] who assessed MD adherence among students from the Medical University of Warsaw. The intake of specific food products in the study group significantly differed from the traditional and modern MD eating principles.

A similar association was observed in a study assessing MD adherence among Greek students in which the majority $(73.5 \%)$ of study participants had low MD adherence. The authors concluded that a significant proportion of students had abandoned traditional MD in favor of more modern diets [24].

The lower MD adherence has also been reported among youth from other countries of the Mediterranean basin. As shown in the literature, there is a clear trend towards the abandonment of MD recommendations [10], a particularly noticeable behavior among youth, including Poland.

Fruits and vegetables are high in antioxidants, dietary fiber and other bioactive compounds known to possess benefits to human health. In addition, regular fruits and vegetables consumption helps control body weight and prevents obesity.

Whole-grain products contain a significant amount of phytic acid, resistant starch and dietary fiber [20]. They also provide high levels of folic acid, zinc and iron as compared to non-whole grain products [7]. Regular consumption of vegetables, fruits and whole grain products is a practical and effective strategy for reducing the incidence of chronic diseases such as cardiovascular disease, including stroke, certain types of cancer, and type-2 diabetes [19]. Nuts have high nutritional value, because they are a rich source of magnesium, vitamin E, B1, phosphorus, iron, dietary fiber, protein, as well as mono- and polyunsaturated fatty acids. Nuts consumption is an important factor reducing the risk of lifestyle-related diseases [15].
In our study, the intake of vegetables according to MD recommendations differed significantly between the studied groups. However, the intake of fruits and nuts differed significantly only in the groups with low and high MD adherence. Only $11.0 \%$ of all study participants followed MD recommendations for daily intake of vegetables and fruits. Similarly, in a study conducted among students from Cyprus the authors reported low intake of vegetables and fruits among the study participants. Only about $30.0 \%$ of the studied young adults consumed more than one serving of fruits and vegetables per day [11].

The results of the meta-analysis carried out by Antonopoulou et al. [1] reported an insufficient intake of vegetables, fruits and nuts, as well as grain products among Spanish students. The intake of bread in the diets of female students from Warsaw was significantly lower compared to the diets of Greeks in 1978, but similar to the intake of bread in the diets of modern Greeks [28]. The intake of grain products in the diets of cosmetology students was comparable in each group, regardless of the number of points obtained.

Legumes contain high amounts of dietary fiber, protein, many vitamins and minerals, and have a low glycemic index. Consumption of legumes reduces the risk of type-2 diabetes, cardiovascular disease and obesity [26]. We reported significant differences in the intake of legumes between the groups with the lowest and moderate-to-high MD adherence (42.7 \pm 70.4 vs. $137.6 \pm 127.1$ and $271.0 \pm 281.7 \mathrm{~g} /$ week). However, university students in Cyprus followed MD recommendations for legumes. Almost $50.0 \%$ of the study participants consumed more than one serving of legumes per week [11]

Milk and dairy products provide many nutrients to the diet, including complete protein, calcium, phosphorus, magnesium, potassium, zinc, selenium, vitamins A, B2 and B12 [5]. Consumption of fermented dairy products reduces the risk of obesity and type- 2 diabetes. The health-promoting effects of dairy products consumption are related to their high content of calcium, some vitamins and protein [20]. The intake of dairy products in the majority of university students in Cyprus complied with MD dietary recommendations week [11].

Our study participants had high intake of dairy, which was inconsistent with MD recommendations. Only the group high MD adherence consumed the recommended servings of dairy products (198.2 \pm $166.7 \mathrm{~g} /$ day). Authors of the meta-analysis assessing MD adherence in different populations of university students had the same conclusions. They found that the intake of milk and its products in the diets of Spanish students was higher than recommended. In addition, the intake of meat was also higher than recommended and comparable to the results of our study [1]. We 
reported significantly higher intake of meat and meat products in the group with low MD adherence compared to the group with high MD adherence (141.0 \pm 100.5 vs. $72.2 \pm 85.6 \mathrm{~g} /$ day). A similar tendency was observed among students from Warsaw whose diets had a significantly higher intake of meat and cheese compared to the Greek population in 1978, which was comparable to the diets of contemporary Greeks living in cities [28]. High consumption of meat, including red and processed meat, is associated with a higher risk of metabolic syndrome and other chronic diseases, including type-2 diabetes. However, the consumption of poultry was inversely correlated with the risk of metabolic syndrome, hypertriglyceridemia and elevated blood pressure. Therefore, health impact of meat consumption depends on its type [14]. According to the MD recommendations, the overall intake of meat, particularly red and processed, should be low [3].

Oily sea fish such as herring, mackerel and salmon are good sources of omega-3 fatty acids and vitamin D. They are rich in minerals and complete protein. The dietary intake of omega-3 polyunsaturated fatty acids (n-3 PUFAs) in fatty sea fish may significantly reduce the risk of cardiovascular disease and have possible anti-inflammatory effects $[4,12]$. In our study, students with the highest MD adherence consumed more than twice as many fish as students from with the lowest MD adherence $(108.5 \pm 86.9$ vs. $48.0 \pm 34.7 \mathrm{~g} /$ week $)$. However, most of the studied participants did not meet the recommended weekly fish intake. In the group of university students from Cyprus, only $28.0 \%$ met the weekly intake recommendations for fish, which is at least 2-3 times a week [11].

Monounsaturated fatty acids (MUFAs) in olive oil have many health benefits, e.g., they reduce the risk of type- 2 diabetes. In addition, adding olive oil to meals may prevent weight gain by lowering postprandial glucose levels [2]. In our study, the use of olive oil was declared by a significantly greater number of students with moderate and high MD adherence $(12.1 \pm 9.6$ and $12.0 \pm 5.0 \mathrm{~g}$ /day) compared to students with low MD adherence $(6.8 \pm 5.1 \mathrm{~g} /$ day). The majority of university students from Cyprus consumed high amounts of olive oil [11]. Among Spanish students a significantly higher olive oil intake was recorded in the group with higher MD adherence compared to the group with low MD adherence [8]. However, this association was not confirmed in all groups of Spanish students [1].

About $30.0 \%$ of university students from Cyprus consumed sweets several times a day [11], which is in line with similar findings from the studies assessing dietary patterns of Spanish students [1] and American adolescents [21]. In our study, the intake of sweets was significantly higher in the group with low and moderate MD adherence compared to the group with high MD adherence $(52.1 \pm 34.2 ; 52.8 \pm 35.5$ vs. $35.6 \pm$ $32.5 \mathrm{~g} /$ day). Sweets and snacks are inversely associated with diet quality. In our study, higher sweets intake was directly associated with lower MD adherence.

When it comes to alcohol, its intake was low and did not differ significantly between the study groups. Similar results were observed in a group of Spanish students. However, the alcohol consumption was higher in the group of students living away from home [1]. It has been reported that moderate alcohol consumption may protect against some chronic diseases [6]. To obtain more reliable study results we assessed dietary intakes of food groups not typical of the traditional MD, such as sweets, drinks, eggs and potatoes. Their high reported intakes may have adversely affected the study results. Some authors included potatoes in the average daily intake of grains [13], and did not assess intakes of additional products, whereas other researchers assessed the intake of additional food products [25].

The dietary patterns of studied Polish cosmetology students differed significantly in the intake of dietary fiber depending on the group. The intake of dietary fiber in the group with the highest MD adherence was $30.0 \pm 9.4 \mathrm{~g} /$ day, and in the group with the lowest MD adherence only $16.2 \pm 6.2 \mathrm{~g}$ /day. Insufficient dietary fiber intake was also reported in a study conducted among Greek students - almost 70.0\% of men and over $50.0 \%$ of women failed to meet the recommended intake of dietary fiber [6], which resulted from the insufficient intake of whole-grain products, vegetables and fruits. Dietary fiber lowers the risk of cardiovascular diseases [6]. In our study, the energy intake of the studied diets was comparable to the results obtained by Chourdakis et al. [6] and did not differ significantly between the groups.

\section{CONCLUSION}

Dietary patterns of studied cosmetology students of the School of Physiotherapy in Poland did not adhere to the Mediterranean diet recommendations. Changes to these unhealthy eating habits would help improve quality of students' lives today and in the future.

\section{Conflict of interest}

The Authors declare no conflict of interest.

\section{REFERENCES}

1. Antonopoulou, M., Mantzorou, M., Serdari, A., Bonotis, K., Vasios, G., Pavlidou, E., Trifonos, C., Vadikolias, K., Petridis, D., Giaginis, C. Evaluating Mediterranean diet adherence in university student populations: Does this dietary pattern affect students' academic performance and mental health? International Journal of Health 
Planning and Management, 2020;35:5-21 doi:10.1002/ hpm.2881

2. Assaf-Balut, C., de la Torre, N.G., DuraÂn, A., Fuentes, M., BordiuÂ, E., del Valle, L., Familiar, C., OrtolaA,, A., JimeÂnez, I., Herraiz, M.A., Izquierdo, N., Perez, N., Torrejon, M.J., Ortega, M.I., Illana, F.I., Runkle, I., de Miguel, M.P., Montañez, C., Barabash A., Cuesta, M., Rubio, M.A., Calle-Pascual, A.L. A Mediterranean diet with additional extra virgin olive oil and pistachios reduces the incidence of gestational diabetes mellitus (GDM): A randomized controlled trial: The St. Carlos GDM prevention study. PLoS ONE. 2017;12(10): e0185873 doi.org/10.1371/journal.pone.0185873

3. Babio, N., Sorli, M., Bulló, M., Basora, J., IbarrolaJurado, N., Fernández-Ballart, J., Martínez-González, M.A., Serra-Majem, L., González-Pérez, R., SalasSalvadó, J. Association between red meat consumption and metabolic syndrome in a Mediterranean population at high cardiovascular risk: cross-sectional and 1-year follow-up assessment. Nutrition, Metabolism \& Cardiovascular Diseases, 2012; 22(3): 200-207 doi:10.1016/j.numecd.2010.06.011

4. Binia, A., Vargas-Martínez, C., Ancira-Morenoc, M. Gosoniu, L.M., Montoliu, I.,Gámez-Valdez, E., SoriaContreras, D.C., Angeles-Quezada, A., GonzalezAlberto, R., Fernández, S., Martínez-Conde, D., Hernández-Morán, B., Ramírez-Solano, M., PérezOrtega, C., Rodríguez-Carmona, Y., Castan, I, RubioAliaga, I., Vadillo-Ortega, F., Márquez-Velasco, R., Bojalil, R., López-Alvarenga, J.C., Valet, P., Kussmann, M., Silva-Zolezzi, I., Tejero, M.E. Improvement of cardiometabolic markers after fish oil intervention in young Mexican adults and the role of PPAR $\alpha$ L162V and PPAR $\gamma 2$ P12A. Journal of Nutritional Biochemistry, 2017;43:98-106 doi.org/10.1016/j.jnutbio.2017.02.002

5. Cavero-Redondo, I., Alvarez-Bueno, C., Sotos-Prieto, M., Gil, A., Martinez-Vizcaino, V., Ruiz, J.R. Milk and Dairy Product Consumption and Risk of Mortality: An Overview of Systematic Reviews and Meta-Analyses. Advances in Nutrition, 2019;10:97-104 doi.org/10.1093/ advances/nmy128.

6. Chourdakis, M., Tzellos, T., Pourzitaki, C., Toulis ,K.A., Papazisis, G., Kouvelas, D. Evaluation of dietary habits and assessment of cardiovascular disease risk factors among Greek university students. Appetite, 2011;57:377-383 doi:10.1016/j.appet.2011.05.314

7. Christensen, C.B., Mikkelsen, B.E., Toft, U. The effect of introducing a free breakfast club on eating habits among students at vocational schools. BMC Public Health. 2019;19:369 doi.org/10.1186/s12889-019-6701-9

8. Cobo-Cuenca, A.I., Garrido-Miguel, M., SorianoCano, A., Ferri-Morales, A., Martínez-Vizcaíno, V. Martin-Espinosa, N.M. Adherence to the Mediterranean Diet and Its Association with Body Composition and Physical Fitness in Spanish University Students. Nutrients, 2019;11:2830 doi:10.3390/nu11112830

9. Dehghan, M., Ilow, R., Zatońska, K., Szuba, A., Zhang, X., Mente, A., Regulska-Ilow, B. Development, reproducibility and validity of the food frequency questionnaire in the Poland arm of the Prospective
Urban and Rural Epidemiological (PURE) study. Journal of Human Nutrition and Dietetics, 2012;25: 225-232 doi: 10.1111/j.1365-277X.2012.01240.x.

10. García Cabrera, S., Herrera Fernández, N., Rodríguez Hernández, C., Nissensohn, M., Román-Viñas, B., Serra-Majem y, L. KIDMED test; prevalence of low adherence to the Mediterranean Diet in children and young; a systematic review. Nutrición Hospitalaria, 2015;32(6): 2390-2399 DOI:10.3305/nh.2015.32.6.9828

11. Hadjimbei, E., Botsaris, G., Gekas, V., Panayiotou, A.G. Adherence to the Mediterranean Diet and Lifestyle Characteristics of University Students in Cyprus: A Cross-Sectional Survey. Journal of Nutrition and Metabolism. 2016; Article ID: 2742841 doi. org/10.1155/2016/2742841

12. Handeland, K., Skotheim, S., Baste, V., Graff I.E., Frøyland, L., Lie, Ø., Kjellevold, M., Markhus, M.W., Stormark, K.M., Øyen, J., Dahl, L. The effects of fatty fish intake on adolescents' nutritional status and associations with attention performance: results from the FINS-TEENS randomized controlled trial. Nutrition Journal, 2018;17, 30 DOI 10.1186/s12937-018-0328-Z

13. Iaccarino Idelson, P., Scalfi, L., Valerio, G.: Adherence to the Mediterranean Diet in children and adolescents: A systematic review. Nutrition, Metabolism \& Cardiovascular Diseases, 2017;27: 283-299 doi. org/10.1016/j.numecd.2017.01.002

14. Kim, Y., Je, Y.: Meat Consumption and Risk of Metabolic Syndrome: Results from the Korean Population and a Meta-Analysis of Observational Studies. Nutrients, 2018;10:390 doi:10.3390/nu10040390

15. Kulik, K., Waszkiewicz-Robak, B., Biller, E.: Deklarowana a oznaczona analitycznie zawartość składników odżywczych w różnych rodzajach orzechów [Labelled and analytically determined content of nutrients in various nut types]. Postępy techniki przetwórstwa spożywczego, 2019;2:49-56. (in Polish)

16. Kunachowicz H., Przygoda B., Nadolna I., Iwanow K.: Tabele składu i wartości odżywczej. [Food Composition Tables]. Warsaw, PZWL, 2020. (in Polish)

17. Easzek M., Nowacka E., Gawron-Skarbek A., Szatko, F.. Negatywne wzorce zachowań zdrowotnych studentów. Część II. Aktywność ruchowa i nawyki żywieniowe [Negative behavior patterns of students. Part II. Physical activity and eating habits]. Problemy Higieny i Epidemiologii, 2011;92(3):461-465. (in Polish)

18. Martínez-González, M.A., Hershey, M.S., Zazpe, I., Trichopoulou, A. Transferability of the Mediterranean Diet to Non-Mediterranean Countries. What Is and What Is Not the Mediterranean Diet. Nutrients, 2017;9:1226 doi:10.3390/nu9111226

19. Roager, H.M., Vogt, J.K., Kristensen, M., Hansen, L.B.S., Ibrügger, S., Morkedahl, R.B., Bahl, M.I., Lind, M.V., Nielsen, R.L., Frøkior, H., Gøbel, R.J., Landberg, R., Ross, A.B., Brix, S., Holck, J., Meyer, A.S., Sparholt, M.H., Christensen, A.F., Carvalho, V., Hartmann, B., Holst, J.J., Rumessen, J.J. Linneberg, A., Sicheritz-Pontén, T., Dalgaard, M.D., Blennow, A., Frandsen, H.L., Villas-Bôas, S., Kristiansen, K., Vestergaard, H., Hansen, T., Ekstrøm, C.T., Ritz, C., 
Nielsen, H.B., Pedersen, O.B., Gupta, R., Lauritzen, L., Licht, T.R. Whole grain-rich diet reduces body weight and systemic low-grade inflammation without inducing major changes of the gut microbiome: a randomised cross-over trial. Gut, 2019;68: 83-93 doi:10.1136/ gutjnl-2017-314786

20. Schwingshackl, L., Schwedhelm, C., Galbete, C., Hoffmann, G. Adherence to Mediterranean Diet and Risk of Cancer: An Updated Systematic Review and Meta-Analysis. Nutrients, 2017;9:1063 doi:10.3390/ nu9101063

21. Slining, M.M., Popkin, B.M. Trends in intakes and sources of solid fats and added sugars among US children and adolescents: 1994-2010. Pediatric Obesity, 2013;8(4): 307-324 doi:10.1111/j.2047-6310.2013.00156.x.

22. Sofi, F., Macchi, C., Abbate, R., Gensini, G., F., Casini, A. Mediterranean diet and health status: an updated metaanalysis and a proposal for a literature-based adherence score, Public Health Nutrition, 2013;17(12):2769-2782 doi:10.1017/S1368980013003169

23. Stefler, D., Malyutina, S., Kubinova, R., Pająk, A., Peasey, A., Pikhart, H., Brunner, E., J., Bobak, M. Mediterranean diet score and total and cardiovascular mortality in Eastern Europe: the HAPIEE study, European Journal of Nutrition, 2017;56(1):421-429 doi: 10.1007/s00394-015-1092-x

24. Theodoridis, X., Grammatikopoulou ,M.G., Gkiouras, K., Papadopoulou, S.E., Agorastou, T., Gkika, I., Maraki, M.I., Dardavessis, T., Chourdakis, M. Food insecurity and Mediterranean diet adherence among Greek university students. Nutrition, Metabolism \& Cardiovascular Diseases, 2018;28: 477-485 doi. org/10.1016/j.numecd.2018.02.007

25. Trichopoulou, A., Orfanos, P., Norat, T., Bueno-deMesquita, B., Ocké, M., Peeters, P.H., van der Schouw, Y.T., Boeing, H., Hoffmann, K., Boffetta, P., Nagel, G., Masala, G., Krogh, V., Panico, S., Tumino, R., Vineis, P., Bamia, C., Naska, A., Benetou, V., Ferrari, P.,
Slimani, N., Pera, G., Martinez-Garcia, C., Navarro, C., Rodriguez-Barranco, M., Dorronsoro, M., Spencer ,E., Key, T., Bingham, S., Khaw, K-T., Kesse, E., ClavelChapelon, F., Boutron-Ruault, M-C., Berglund, G., Wirfalt, E., Hallmans, G., Johansson, I., Tjonneland, A., Olsen, A., Overvad, K., Hundborg, H., Riboli, E., Trichopoulos, D. Modified Mediterranean diet and survival: EPIC-elderly prospective cohort study. BMJ. 2005 doi:10.1136/bmj.38415.644155.8F

26. Viguiliouk, E., Glenn, A.J.,Nishi, S.K., Chiavaroli, L.,Seider, M.,Khan, T.,Bonaccio, M., Iacoviello, L., Mejia, S.B., Jenkins, D.J.A., Kendall, C.W.C., Kahleov, H., Rahelic, D., Salas-Salvad, J., Sievenpiper, J.L.L. Associations between Dietary Pulses Alone or with Other Legumes and Cardiometabolic Disease Outcomes: An Umbrella Review and Updated Systematic Review and Meta-analysis of Prospective Cohort Studies. Advances in Nutrition, 2019;10:308319 doi.org/10.1093/advances/nmz113

27. Zurita-Ortega, F., San Román-Mata, S., ChacónCuberos, R., Castro-Sánchez, M., Muros, J.J. Adherence to the Mediterranean Diet Is Associated with Physical Activity, Self-Concept and Sociodemographic Factors in University Student. Nutrients, 2018;10(8):966 doi:10.3390/nu10080966

28. Zych P., Szostak-Wegierek D.: Ocena zgodności modelu żywienia studentów Warszawskiego Uniwersytetu Medycznego z zasadami diety śródziemnomorskiej [Evaluation of nutritional model compatibility with the principles of the Mediterranean diet in students of the Warsaw Medical University]. Nowa Medycyna, 2013;3:107-110. (in Polish)

Received: 24.05.2021

Accepted: 19.07.2021

Published online first: 26.07.2021 